Ssciendo Studia Anglica Posnaniensia 55s2 (2020): 427-443

doi: 10.2478/stap-2020-0021

\title{
PERMUTATIONS OF REMEMBRANCE AND (COUNTER-) MONUMENTALIZATION: JOHN MCCRAE'S IN FLANDERS FIELDS
}

\author{
ANNA BRANACH-KALLAS ${ }^{1}$
}

\begin{abstract}
The article engages with the cultural impact of John McCrae's canonical poem "In Flanders Fields" (1915), and more specifically the permutations of cultural memory and heritage discourse in In Flanders Fields: 100 Years: Writing on War, Loss and Remembrance, edited by Amanda Betts and published in 2015. It shows how thirteen Canadians explore the revolutionary role of the poem in Canadian collective and individual memory, as well as its omissions and misrepresentations. The article juxtaposes the cultural history of the poem with Wilfred Owen's "Dulce et Decorum Est" and its contemporary transformations, also showing how selected essays in the collection bridge the First World War with other armed conflicts. Applying Ann Rigney's terminology, the article approaches the poem as a textual monument, demonstrating how "In Flanders Fields" has evolved from the role of a stabilizer in Canadian cultural memory, providing a cultural frame for later recollections, to that of a calibrator, becoming a benchmark for critical reflection on dominant memorial practices.
\end{abstract}

Keywords: Heritage; cultural memory; monumentalization; trauma; body; family memory; witnessing.

\section{Introduction}

The purpose of this article is to engage with the permutations of cultural memory and heritage discourse in In Flanders Fields: 100 Years: Writing on War, Loss and Remembrance, edited by Amanda Betts and published in 2015. The collection is composed of historical accounts, personal reflections, academic essays, fiction and poetry, all inspired by John McCrae's life and his famous poem "In Flanders Fields". The thirteen contributors are renowned Canadian scholars (Tim Cook, Wade Davis, Jonathan Vance), fiction writers, poets, and playwrights (Margaret

$1 \quad$ Nicolaus Copernicus University, ul. Bojarskiego 1, 87-100 Toruń, kallas@umk.pl 
Atwood, Joseph Boyden, Hannah Moscovitch, George Elliott Clarke, Frances Itani, Patrick Lane), a journalist (Mary Janigan), a soldier and politician (Roméo Dallaire), a physician and writer (Kevin Patterson), and a sportsman and MP (Ken Dryden). The book is beautifully edited, with many photographs from the First World War and current rituals of commemoration, as well as reproductions of maps and paintings. Published at the centenary of the 1914-1918 conflict, the collection might be seen as one of the multiple examples of the current anniversary boom, and the increasing interest in commemorating dates and historical events (see Ashplant, Dawson \& Roper 2000: 4). However, as I intend to demonstrate in my analysis by tracing the fate of the poem and its creator in the war years, as well as the different political, social, and cultural contexts of its post-war interpretations, In Flanders Fields: 100 Years also highlights "the production of 'new' cultural memory by war and its transformation into manifest and intangible heritage through the course of time after the war" (Gegner \& Ziino 2011: 1). ${ }^{2}$ Approaching remembrance after Astrid Erll and Ann Rigney not only as an effort to preserve earlier stories but as a process of "acting out a relationship to the past from a particular point in the present" (2009: 2), I attempt to illustrate the tension between the strategies of monumentalization and counter-momumentalization, i.e., the construction of "In Flanders Fields" as a Canadian cultural icon, endorsing a celebratory rhetoric of war, and the questioning of the symbolic status of the poem, as well as the traditional war discourse. In my analysis I first focus on a reinterpretation of the poet's life and what "In Flanders Fields", as well as its gaps and absences, might reveal about war experience; subsequently, I examine the cultural life of the poem, focusing on its fluctuating ideological role as part of Canadian heritage; finally, I explore how the poem continues to inspire reflection on memory in new affective contexts, thus departing from its original interpretation.

\section{The soldier-poet: Glory and trauma}

Born in Guelph in a family of Scottish-Presbyterian immigrants in 1872, since early childhood John McCrae had loved the military. At the age of fourteen he joined the Guelph Highland Cadet Corps, in which he excelled, and later was

2 The concept of cultural memory refers to certain established lieux de mémoire, which bring together individuals and communities in remembering a shared past. Cultural memory is dependent on various media, discourses, and representations of the past. Moreover, in recent years, scholars have begun to approach cultural memory as a process, involving an active performance of the individual's or group's relationship to the past, rather than its passive reproduction (Erll \& Rigney 2009: 1-2). As to heritage, a traditional understanding of this concept includes objects, museums displays, locations, and events. Yet recently scholars have also departed from an approach to heritage as a physical thing, stressing the importance of acts of remembrance and cultural consumption, which influence individual and group identity (Waterton \& Watson 2015a: 1; Moody 2015: 113). 
active in the local militia units. McCrae was a particularly gifted young man: he was the first Guelph student to win a scholarship to the University of Toronto, from which he graduated in 1894 with a bachelor's degree in arts and languages, and in 1898 an honours degree in medicine. He studied with the famous Canadian doctor William Osler in Baltimore, Maryland, and subsequently was offered a fellowship in pathology at McGill University. However, when the Boer War broke out in 1899 he was among the 7,300 Canadians who enlisted and left for South Africa with the Royal Canadian Regiment. Although the campaign was harsh and exhausting, he did not lose his enthusiasm and believed that soldiering was his vocation (Hurst 2003: 66-67; Cook 2015: 17-25). After the South African War McCrae became a famous pathologist with a private practice in Montreal; by many he was considered the most gifted physician of his generation. He lectured at McGill, published academic papers and textbooks, and became a member of the prestigious Royal College of Physicians in London. McCrae was not only "a healer and warrior" (Cook 2015: 17), but also a great humanist and a recognized poet. He joined the Pen and Pencil Club, a group of eminent Canadian artists that included Maurice Cullen and Stephen Leacock. Much of his pre-war poetry, inspired by his experience of disease and war, explores the dark themes of death and the afterlife (Hurst 2003: 67-71; Cook 2015: 26-32).

McCrae was forty-one years old at the onset of the First World War, and to his profound disappointment he was deemed too old to be a soldier. He went to Europe as a surgeon at the rank of Major and was quickly promoted to LieutenantMajor. He harboured much resentment being barred from true soldiering; instead of a Red Cross armband that would identify him as a non-combatant, he wore his revolver and sword. However, the cargo of death he had to deal with every day soon took a heavy toll on the physician. The death of twenty-two-year-old Alexis Helmar, who was dismembered in a shell explosion on May 2, 1915, inspired "In Flanders Fields". McCrae's letters and his friends' accounts confirm that after days of incessant bombing he suffered from lack of sleep, forcing himself to eat to be able to perform his duties. He was increasingly depressed by the loss of many of his companions. Eventually, at the age of forty-four, McCrae contracted, and died of, meningitis on January 28, 1918. Sadly, his promotion to consulting physician for the First British Army came a few days after his demise (Hurst 2003: 72-75; Cook 2015: 33-51).

Although as a trauma surgeon, $\mathrm{McC}$ rae operated on wounded men and treated victims of German gas attacks every day, he does not mention the bloody details of his daily work in his poetry; the monumentalization of glory and sacrifice elides the vulnerability of both patients and doctors. This might have been a response to Victorian ideals of masculinity, defined by stoicism, reticence, and self-control. Moreover, pain responses "were constituted in both the political forces of the state at war and the social dynamics of interpersonal relationships, 
complicating humanitarian practices" (Carden-Coyne 2014: 5). Medical personnel tended to repress their emotional suffering, responding with determined stoicism and resilience to the "world of hurt" around them. Rather than superficial idealism, such an approach might be seen as an important coping strategy (Acton \& Potter 2015: 1-2, 48). In his essay "Forged in Fire", included in Amanda Betts' collection, Tim Cook, Canadian expert on the history of the First World War, depicts McCrae's gradual physical and moral decline, and argues that the Canadian physician suffered from what today we would refer to as PTSD (Cook 2015: 48). McCrae seems also to have been affected by survivor guilt, a common condition among those whose lives are spared in traumatic circumstances, and who are subsequently tormented by the injustice of other deaths and the enigma of their own survival. The inability to save others leads to self-condemnation, particularly in the case of medical personnel (see Herman 1992: 53-54; Lifton 1996 [1979]: 145-148; Acton \& Potter 2015: 32). The poet's extraordinary success must have rendered his feelings of shame and guilt even more acute. He aged prematurely and isolated himself from others. In Cook's view, tormented by the mass death around him, he found relief in continuing his mission, thus keeping faith with the fallen (Cook 2015: 48-50). Absolute dedication to others is also a frequent approach among trauma survivors, who thus attempt to pay their debt to the dead, as well as "to integrate reliving experiences into their lives in a contained, even socially useful manner" (Herman 1992: 41; see also Lifton 1996 [1979]: 145).

In "Soldier Surgeon, Soldier Poet", Kevin Patterson, a Canadian army doctor and writer, discerns, nevertheless, a tension between McCrae's multiple personas as a poet, soldier, and healer (2015: 128). In his opinion, the contract that appears in McCrae's poetry between the glorious dead and the living "is simultaneously evidence of a bloody obduracy and of the depth to which he was shaken by the loss he saw every day. The one thing that could make that loss even worse for him would be for it to be meaningless. He could not face that. And he didn't" (Patterson 2015: 129). Observing daily the victims of the first industrialized homicide, he deluded himself that their agony had a deeper sense (Patterson 2015: 123). For Patterson, the central image of "In Flanders Fields", the dead urging the living to continue their struggle, is deeply shocking and unethical. In his view, McCrae

\footnotetext{
adopts the voices of the dead, the men who have just lost the lives they were supposed to have lived - their children, the furniture they would have made, the houses they were to have built, the tender moments with their wives that were to have lingered as warming memories in their older years - and urges on more convulsive homicide. It is an act of astonishing and deluded presumption: Who would assume that, if the masses of war dead could speak - nearly twenty million in that conflagration - what they would urge on would be more of it? (2015: 122)
} 
With a present-day sensitivity, and perhaps a slightly ahistorical bias, Patterson questions McCrae's sanity, interrogating how a physician could deliver such a message in light of the mass death surrounding him. Both Joanna Bourke and Ana Carden-Coyne, cultural historians of the First World War, argue that the first industrialized conflict caused a "corporeal crisis" (Bourke 1996: 210-221, 251) and "fragmented the ideal of the whole, modern body" (Carden-Coyne 2014: 353). Men were often horribly maimed, or pulverized into nothingness. Patterson attempts to fill in the blanks of McCrae's poem and describes field surgery in terms of "damage control", the physician's task consisting in repairing the men's maimed bodies to make them ready to fight again. While there is evidence that medical personnel experienced serious doubts about their task during the First World War (see Carden-Coyne 2014: 311), they are not voiced in McCrae's melancholic poetry, the poet turning away from the carnage and calling on the living to sacrifice themselves for the sacred Cause (Patterson 2015: 116-123). Patterson's graphic description of catastrophic devastation is complemented by Wade Davis, Canadian anthropologist, filmmaker and photographer, who in "Of War and Remembrance" insists on figures - the number of the dead, wounded, amputees, disabled, blind, shell-shocked - i.e., the human cost of war. Both essays can be seen as instances of counter-monumentalization, as they resist the monumentalization of war and sacrifice by reclaiming bodily vulnerability, as well as affective responses to the medical war that would have been strongly condemned a hundred years ago (Davis 2015: 157-158).

\section{Remediation: The cultural life of "In Flanders Fields"}

The publication history of McCrae's poem, its reception, and success are extraordinary. Initially rejected by The Spectator, "In Flanders Fields" was published anonymously in the satirical magazine Punch on December 8, 1915. The Washington Post printed the poem in January 1916, and it appeared in the Vancouver Daily World, its Canadian debut, only in March 1916. The form of the rondeau, its simple metre, rhyme, and diction, made it easy to memorize; it was soon recited by British imperial troops all over the world (Hurst 2003: 74). The message of the poem, the belief in the righteousness of the Cause to be continued by the living, "connected deeply with societies that had lost so much and would undoubtedly be called upon to give even more before the war was won" (Vance 2015: 190). The elegy, which soon gained the status of cultural icon, contributed to the solidification of the Canadian myth of the Great War as a meaningful sacrifice in defence of civilization and a nation-building event. It also shaped, fuelled, and inspired the post-war cult of the fallen as part of the national mythology (Vance 1997: 198-201, Vance 2005: 410-411). Verses of the poem were cited on graves and war memorials, and the central image of the torch 
appeared on many monuments. It has been recited not only on Remembrance Day in Canada, but also on Anzac Day in Australia and New Zealand (Vance 2015: 198-199). The phrases used by McCrae - "keeping the faith and holding the torch - had entered the vernacular as shorthand for duty and obligation" (Vance 2015: 197). "In Flanders Fields" also popularized the poppy as a symbol of death in combat and remembrance of those who died in war (Hurst 2003: 76). McCrae's tragic death at the front "added another poignant layer of meaning to the poem" (Vance 2015: 191).

The cultural life of "In Flanders Fields" is a perfect example of the complex process that Erll and Rigney refer to as remediation. The scholars claim that "When we look at the emergence and 'life' of memory sites, it becomes clear that these are based on repeated media representations, on a host of remediated versions of the past which 'converge and coalesce' (...) into a lieu de mémoire, which create, stabilize and consolidate, but then also critically reflect upon and renew these sites" (2009: 4). After its publication, "In Flanders Fields" quickly became the anthem of the Great War generation and was used to promote various patriotic causes. For instance, it was employed to encourage people to buy Victory Loans in Canada and war savings certificates in Australia, as well as to contribute to the American Red Cross Society's campaign (Vance 2015: 193). In one of the most bitter essays in the collection, suggestively entitled "Treason to Their Memory", journalist Mary Janigan, an expert on Canadian public policy, comments on the propaganda usage of McCrae's poem in the wartime election of 1917. During the campaign, the supporters of Sir Robert Borden, the Union Government, and general conscription completely appropriated "In Flanders Fields" as "ammunition" against their fellow Canadians (Janigan 2015: 93). Any opposition to recruitment was presented as a betrayal of the fallen. Lines of the poem served to vilify Quebeckers, who, for various historical reasons, were reluctant to enlist. After they won the election, the Unionists introduced a series of acts that redefined Canadian nationality by promoting a discourse of duty and obligation to the state, at the same time dividing the nation along ethnic and political lines. The Military Service Act, which conscripted men aged twenty to forty-four for the duration of the war, the infamous Regulation 17, which limited the teaching of French in Ontario, the War-time Elections Act, which enfranchised women whose relatives were at the front at the cost of enemy aliens and conscientious objectors, all generated conflict and resentment (Janigan 2015: 81-88). Janigan sadly concludes her discussion of one of the most divisive moments in Canadian history by suggesting that "'IN FLANDERS FIELDS' might have reinforced the Western Front with patriots, but it also reinforced Canada's two solitudes" (2015: 92).

As emphasized by renowned Canadian cultural historian Jonathan Vance in his essay "A Moment's Perfection", the rondeau also became so popular in 
Canada and the whole of the British Empire "because of the absence of any meaningful copyright protection" (2015: 190). The reproduction of the poem was beyond McCrae's control, and he did not have any share in the profits that it generated. In the post-war years, "In Flanders Fields" became an "all-purpose metaphor" (Vance 2015: 203), which was used and abused in various political, sports, and commercial contexts, radically divergent from its original message. Recruited during the Second World War, it "came to symbolize the fundamental continuity between the two wars" (Vance 2015: 202). Lines of the poem were quoted by a Nazi propagandist to discourage Americans from joining World War II; in a protest against archaeological work on Maori burial sites; in a tribute to John F. Kennedy after his assassination; in an attempt to impeach President Bill Clinton. It was evoked to advertise men's clothes and surgical dressings; to encourage motion picture studios to produce more Canadian films; to campaign for capital punishment. Racehorses were named Flanders Fields, and lines of the poem were often cited to celebrate various sports events (Vance 2015: 199-203). As Ken Dryden, the famous Canadian hockey player, MP and writer, reminisces in his essay "The Torch", in 1952 the poem appeared on the walls of the Montreal Canadiens' dressing room, to inspire esprit de corps, and remembrance in and of the Canadian legendary ice hockey team (2015: 99-101).

Vance demonstrates that in the post-war years, "In Flanders Fields" enjoyed an uncontested reputation as one of the greatest, if not the greatest, poem of the Great War. It inspired "a separate subgenre" in Canadian literature: Ralph Connor, among others, and many other lesser known poets, produced verses of little artistic quality which, however, reaffirmed the conviction that the living will continue to hold the torch in a righteous Cause. In 1919, a collection of McCrae's verse edited by Andrew Macphail was at the top of the non-fiction best-seller list. The poem was considered a masterpiece not only in Canada, where it was printed in almost every anthology of Canadian poetry in the post-war years, but also in Great Britain and Australia, as well as in the United States. The New York Times declared it "one of the three pre-eminent poems of the war, matched only by Rupert Brooke's "The Soldier" and Alan Seeger's "I Have a Rendezvous with Death". Only in the late 1950s, when the idealism of the Great War generation came under severe criticism, was it accused of naïve sentimentalism and ideological conservatism (Vance 1997: 200; Vance 2015: 191-196, 204-205).

In an important gesture of reassessment, a number of essays in Betts' volume locate McCrae, the colonial medical officer, among the mythologized British modernist poets, whose output, due to the writings of Paul Fussell and others, has shaped the tradition of Great War poetry in the English-speaking world. Wade Davis contemplates the impact of the mass death they witnessed on Robert Graves and Siegfried Sassoon, who, in contrast to John McCrae, Rupert Brooke, and Wilfred Owen, survived the war, yet for many years after the Armistice 
suffered from PTSD. Davis stresses the fundamental differences between those men and the contemporary generation in terms of masculinity ideals, poetic sensitivity, and attitude to death, which allowed them to participate and persevere in a war that we see as cruel and futile today (2015: 159-168). Kevin Patterson and Patrick Lane compare "In Flanders Fields" with Wilfred Owen's poetry, noting the gap between McCrae's more traditional, romantic imagery and the British war-poet's modernist stylistics. A certain unease results from this comparison: while Owen renders the bodily horror of war in a way that shatters the reader even today, McCrae, as has been mentioned above, elides the corporeal destruction that he witnessed at the front. He insists on an honourable conception of death as the ultimate sacrifice for the Cause (Lane 2015: 65). Patterson shares with the reader the fantasy of a meeting between McCrae, Sassoon, and Owen, and comes to the conclusion that they would not have become close friends. Although the three war poets were profoundly injured by war, differences in generation, rank, attitude, and style would have driven them apart. Moreover, while McCrae's poem was celebrated during the war, Sassoon's and Owen's poetry, because of their bitter tone and modernist experimentation, could only gain acclaim by the end of, and after, the conflict (Patterson 2015: 125-126).

Two literary texts in Betts' collection present an aesthetic challenge to the elisions of "In Flanders Fields" and the Canadian heritage of the First World War. The postmodern story "Poppies: Three Variations" by Margaret Atwood, and the poems of Reverend Captain William Andrew White, the great-grandfather of George Elliott Clarke, challenge the traditional Canadian war narrative. Atwood plays with all the words of McCrae's poem, thus approaching it in an irreverent way that undermines its sacred status, pathos, and sentimentalism. She also exposes its masculinist bias by introducing a woman's point of view. As to George Elliott Clarke, he offers us the unpublished poems of his ancestor, who was the first Black officer in the British Army. They were composed in the Jura, in France, in December 1917, while the Nova Scotian chaplain worked for the Canadian Forestry Corps. This is an important counter-narrative, complementing the official story of Canada's Great War with a non-white perspective, and pointing to entirely new ways of living and representing the war.

\section{4. (Dis-)continuities: Family legacy, affects, and witnessing}

The central message of "In Flanders Fields" not to break faith and to carry the torch has inspired interesting reinterpretations, which radically depart from the original context of the battlefield and the pleading not to forget the fallen. In their respective essays, Canadian poets and fiction-writers, Patrick Lane, Frances Itani, and Joseph Boyden, all ruminate about their ancestors who took part in the First World War, and its impact on family life. According to Jay Winter, during and 
immediately after the Great War, "Remembrance - within families and among families - provided a way to live with the war" (J.Winter 1999: 44). The war narrative, filtered through stories, photographs, letters and journals, was passed on to the following generations as "a script of sadness, but also of survival" (J.Winter 1999: 46). Winter contends that after the death of eyewitnesses to the war, family memories continue to shape an active understanding of the past. They function as a family heirloom, which haunts the descendants of servicemen in the aftermath of conflicts (J.Winter 2001: 65).

In this context, "In Flanders Fields" gains very personal meanings, signifying pain, trauma, and grief far beyond the war zone. In his essay "The Wars" Lane reminisces about the disarray provoked in his family by his father's enlistment in the Second World War, and his return as a shattered stranger when the conflict was over. He highlights the discomfort and puzzlement the words of McCrae's poem caused in him on Remembrance Day when he was a child (2015: 59, 6872). Itani confesses that stories of the war experience of her extended family, passed from generation to generation, have inspired her "to bear witness, long after events have occurred" (2015: 171). She also draws the reader's attention to the emotional anguish of those who remained on the home front, the soldier's closest family, but also more distant relatives and friends, all affected by the departure of one single man (2015: 174). This image of a community shattered by war is reminiscent of the concept of circles of mourning, proposed by French historians of the Great War, Stéphane Audoin-Rouzeau and Annette Becker (2014: 204-210), which reveals the depths of unexplored agony and grief suffered by civilians during armed conflicts. Boyden's existence, in turn, as he reflects in "Three Tours of Flanders", has been marked by his father's participation in the Second World War. Although they took part in two different wars, the writer sees a profound connection between his father and John McCrae: both were decorated medical officers and administrators of field hospitals (Bodyen 2015: 219). Lane's, Itani's, and Boyden's intimate testimony of lives disrupted by armed conflicts highlights an important shift in the perception and remembrance of war from a focus on the army and politics to stories of intimate and individual experience (see Horne 2014: 638; J.Winter 2014). In this light, the military front and the home front appear as porous formations, causing profound economic, social, and intimate transformations; wounds are experienced far beyond the theatre of war, which causes damage and pain long after the cessation of hostilities.

Furthermore, McCrae's life and poem have inspired travels to the war zone that reconceptualise the meaning of heritage and acquire an epiphanic function. For both Itani and Boyden revisiting the battlefields of the First World War had a deeply personal significance. David W. Lloyd approaches such journeys as secular pilgrimages, triggered by family memory of the conflict. For the pilgrims, 
travel provides "a discourse between an imagined landscape and the landscape itself" (Lloyd 1998: 218). Importantly, remembering at the site of conflict is not "a passive activity" (Lloyd 1998: 218). Such journeys involve an important encounter with battlefields as heritage sites, during which landscape, "the last witness of the war" (C.Winter 2016: 81), inscribes itself onto the traveller's body. This is a multi-sensual, phenomenological experience that causes radical transformation (Waterton \& Watson 2015b: 32). Jennifer K. Ladino refers to the affective forcefulness of physical environments, both natural and built ones, in terms of "affective agency", which, in her opinion, "is not a product of individual consciousness or will but rather a collaboration between human and nonhuman actors" (2019: 15). In this perspective, affects emanate from landscape and shape our attitudes not only about the past war but also about issues more contemporary to us (Ladino 2019: 11, 27). In "Messages to the Living, Messages to the Dead", Itani confesses that upon visiting the battlefields where McCrae worked during the First World War and the In Flanders Fields Museum in Ypres, Belgium, named after his poem, she felt the pressure to honour every man who died in the war, each existence destroyed by the conflict. In this barren landscape the writer realized that, in spite of the "abyss of awareness" (2015: 174) that she fell into while researching the history of the First World War, overwhelmed by the details of mass death and destruction, it is the responsibility of the artist to reveal "what armed hostility truly means" (2015: 184). Joseph Boyden also gives us a very private account of his travels to Ypres and the In Flanders Fields Museum. Trying to imagine what his father and McCrae witnessed during their wars while visiting the battlefields of Flanders, Boyden admits that, despite years of research and reflection, much of this experience remains unclear to him. His uncertainty and the sense of inadequacy he experiences turn him into an "affect alien" who, according to Ladino (2019: 24), tends to feel unqualified to interpret particular memory sites. Yet ultimately, the visit provides Boyden with an existential insight: "we are here now. Yes, we are here now in part to remember and to honour the past. But we are here now. We breathe. And we've been given the chance to live with those who live alongside us, to share in their despair and celebrate their happy moments" (2015: 224). Importantly, the haunting trauma of the war is thus mobilized for more present and future-oriented transformation; rather than paralyze the writer, it becomes "a space to work from as opposed to something only to be overcome" (Hirsch 2016: 81).

The opening and closing essays in the collection offer the most thoughtprovoking meditation on war trauma and the ethical commitment it creates in the witness, as inspired by "In Flanders Fields." In "Those Who Serve", LieutenantGeneral the Honourable Roméo Dallaire, who served for thirty-five years in the Canadian Armed Forces, asserts that McCrae's poem evokes in him the reality of the battlefield: the overwhelming fear, the smell of gunpowder and blood, the 
screams of children, the terrifying sites of conflict where innocents are exposed to suffering and death (2015: 4). In contrast to Patterson, Dallaire openly admires McCrae's ethical dedication to the war effort and the power of "In Flanders Fields" to inspire others to serve in the armed forces. He emphasizes that the message of duty that resonates in the poem has not lost its relevance today: McCrae still calls Canadians to arms to prevent conflicts and protect others, particularly innocents threatened by genocide (2015: 14). Referring to his own experience in Afghanistan, Syria, and Rwanda, Dallaire highlights the difference between McCrae's more conventional war and the current "dirty wars" fought by children, often intoxicated by drugs and propaganda. Yet, what saved him from despair in those terrifying places was the belief in esprit de corps, and the honourable regimental history that he was also shaping by his determination not to break faith, an attitude similar to McCrae's (2015: 9). In this sense, "In Flanders Fields" remains a "credo" for all those who serve in the armed forces (2015: 6), which also has a soothing impact on their families. In a deeply personal tone, Dallaire draws the reader's attention to the burden of command - the terrible distress suffered by commanders who send their men into action. He discloses that since his service in Rwanda he has suffered from severe trauma, and flashbacks continue to torment him after the loss of men he sent to their deaths (2015: 11-12). The essay is poignant and deeply moving, particularly when confronted with the fact that, unable to deal with PTSD, Dallaire attempted to commit suicide, a personal tragedy documented with admirable honesty in his award-winning book Waiting for First Light: My Ongoing Battle with PTSD (2016). Dallaire's ensuing dedication to humanitarian missions all over the world is reminiscent of McCrae's dedication to his patients during the First World War.

In a way similar to Dallaire, in "Writing About War" Hannah Moscovitch, one of the most popular and award-winning contemporary Canadian playwrights, comments on the asymmetrical guerrilla warfare of today, the unexpected risks encountered by soldiers, and the polytraumas, i.e., the multiple injuries they are exposed to. She examines the difficult ethical decisions the servicemen are forced to make, as a result of which, like McCrae and Dallaire, they often suffer from PTSD and survival guilt. These issues are brilliantly explored in her play "This is War" about Canadian forces in Panjwaii. Importantly, Moscovitch perceives in the contemporary soldiers' loyalty to their dead friends the same fidelity that McCrae showed to the fallen. Their bodies are often tattooed with the names of their lost comrades-in-arms, a form of bodily memory that renders explicit the determination to carry the torch (2015: 240-243). Both Dallaire and Moscovitch seek a redefinition of Canadianness in the involvement of Canadian forces in peace-keeping missions all over the world, however controversial they might be (Moscovitch 2013: 134). The female artist also reflects on her own powerful, yet deeply troubling fascination with war. She admits her loneliness as a playwright, 
isolated by the incomprehension and distaste often manifested by her friends who cannot understand her obsession with sites of conflict, a dark subject considered particularly inappropriate for a woman (Moscovitch 2015: 239). Moscovitch comes to the conclusion that key to her interest in war is the fact that extreme situations generated by armed conflicts expose the depths of human psychology:

\footnotetext{
I've learned from war that the human psyche is bizarrely flexible and complex, that a person is capable both of immense, intelligent selflessness and banal evil, that a single human action can contain heroism and brutality, or callousness and tenderness, that there is nothing simple to say about us. Once you think you've got hold of some truth about humans, war will show you the opposite, and beyond that, something more complex than the opposite. (2015: 243)
}

When all the points of reference are shattered, artists - Moscovitch, Itani, Boyden, Lane, McCrae - feel the compulsion, and the duty, to share their insights with others in their fiction, drama, and poetry.

\section{Conclusions: Permutations of remembrance}

In Flanders Fields: 100 Years highlights the three functions Erll (2009: 36-37) has identified in her study of literature as a medium of collective memory: circulation, storage, and cue. In terms of circulation, McCrae's poem has become an important element of the collective discourse about the First World War. The elegy has played a unique role in circulating a sentimental and idealistic narrative of war remembrance in Canada and beyond. The vision of the past it "stores", or encodes, might be approached as controversial, but it still inspires re-readings and reinterpretations, while many other poetic and fictional works are simply forgotten. As Erll contends, literary works provide significant "retrieval cues"; even in those who hardly remember its lines, the title of McCrae's poem might evoke some associations - with poppies, the cult of the fallen, or the tragedy of war. The critic claims that "Media of collective memory generally, and with regard to their cue-function specifically, are to a large extent subject to idiosyncratic readings, to actualizations according to the knowledge and needs of particular cultures of memory" (2009: 37). The essays collected in In Flanders Fields: 100 Years demonstrate the multiplicity of "cues" generated by the poem at the centenary of its publication. One of them is the comparison drawn by some of its contributors between John McCrae and Wilfred Owen, which, though exposing the complex differences between the two poets, suggests similarities between the cultural history of "In Flanders Fields" and "Dulce et Decorum Est". The memorial practices applied in the collection also bring to mind "Last Post", the poignant poem by Carol Ann Duffy, Britain's Poet Laureate, published in 2009 upon the deaths of Henry Allingham and Harry Patch, the two longest 
surviving soldiers from the Great War. Referring to the bugle that is played in Britain to honour those who died in war, "Last Post" pays tribute to Wilfred Owen, his "Dulce et Decorum Est", and by extension to all war poets, as well as soldiers who lost their lives in the trenches of the First World War. Duffy imagines a reversal of history, speculating about what would happen if time ran backwards and the dead of the Great War could resume their lives. She thus asserts the importance of Owen's poem but also rebels against its dark legacy. Similarly, while paying homage to its creator, In Flanders Fields: 100 Years celebrates McCrae's elegy, acknowledges its significance as part of the Canadian heritage of the 1914-1918 war, and defies its iconic authority.

Taking the above into consideration, it is justifiable to argue that the essays in Amanda Betts's collection construct "In Flanders Fields" as a textual monument. In "The Dynamics of Remembrance: Texts Between Monumentality and Morphing", Rigney contends that certain literary texts are granted special cultural significance and "continuously morph into the many other cultural products that recall, adapt, and revise them in both overt and indirect ways" (2008: 349). "In Flanders Fields" fulfils at least three of the roles such literary monuments play in the performance of cultural memory, as discussed by Rigney (2008: 350-352). Firstly, the poem can be seen as a stabilizer which, in the post-war years, provided cultural frames for the recollection of the First World War and reinforced the sense of communality. This celebratory tone is most striking in the essays of Cook, Dryden, and Dallaire, who stress the relevance of the poem today as part of a "living heritage" (Viejo-Rose \& Stig Sørensen 2015: 293) that continues to provoke profound reflection on the past and the present.

Secondly, the essays gathered in In Flanders Fields: 100 Years approach McCrae's elegy as an object of recollection. For Rigney, recall and remediation of canonical texts "represent important means of keeping earlier narratives "up to date', that is, memorable according to the norms of the new group" (2008: 351). While recognizing the poem's canonical status in Canadian culture, Vance and Janigan interrogate the social and cultural circumstances of its reception and reproduction. They thus demonstrate that cultural memory is always a negotiation between the legacy of the past and the needs and desires of the present (see Olick 2008: 159). In the same way, they redefine heritage as "a discourse about the past which is ever in fluctuation" (Moody 2015: 113), proposing metacultural insights that reveal "the continuities and discontinuities in the social, political, economic and other processes and reconfigured space and time that create and represent it" (Silverman 2015: 70).

Finally, Patterson, Atwood, and Davis in particular approach "In Flanders Fields" as a calibrator, subject to radical revision, not merely remediation. They propose a critical form of cultural remembrance whereby the challenge to the monumentality of the canonical work serves to render it more malleable and to 
reflect on the mnemonic frameworks it has shaped (Rigney 2008: 352). They recognize the poem's shortcomings and expose its conservatism, ideological consensus, and possible distortions. This counter-monumentalizing perspective accords with the recent trend in Canadian literary criticism to approach national culture as an industry regulated by a literary star system, an inflexible apparatus of selection and exclusion (see McGregor, Rak \& Wunker 2018). While exposing the hidden agenda of literary representativeness and the publishing industry, the texts under consideration ask thought-provoking questions about the ideological foundations of CanLit, and "refuse" McCrae's poem by reclaiming other voices and perspectives, and highlighting the power of representation, as well as the omissions of canonical formations.

As I tried to demonstrate in my analysis, Betts' collection confirms the role of "In Flanders Fields" as an icon, showing its unceasing impact on individual and collective lives. The juxtaposition of McCrae with Owen, and "In Flanders Fields" with "Dulce et Decorum Est," serves this monumentalizing purpose as well, claiming a place for the colonial poet and his work within the canon of First World War poetry. A the same time, the volume opposes the pull of monumentalization by exploring the gaps and elisions of the poem, the morbid underside of the medical war, and the (ab)uses of McCrae's elegy within the heritage policies of the nation state. It illustrates a wide variety of different media that have contributed to the cultural memory of the poem, adding multiple layers of memories, events, discourses, and new representations, which, together with the visual material included in the book, form what Erll and Rigney (2009: 2) refer to as specific "medial frameworks" of remembering. While "In Flanders Fields" is a lieu de mémoire by itself, the volume invokes other important elements of heritage, from symbolic objects such as the poppy, war memorials, and commemorative rituals, through the battlefields of Flanders and the In Flanders Fields Museum, to the Montreal Canadiens' dressing room, all bound by McCrae's poem. As a result, by showing the permutations in the interpretations and usage of the poem over a century, In Flanders Fields: 100 Years: Writing on War, Loss and Remembrance moves beyond an understanding of cultural memory and heritage as fixed and unchanging, to embrace a more complex understanding of these concepts as dynamic processes, involving various people and communities. The engagement of various agents in the construction of cultural memory and heritage is illustrated by the heterogenous social groups the contributors refer to (family, army, medical personnel, sports team, nation). Significantly, by situating different responses to McCrae's poem in dialogue with one another, the essays analysed above relocate "In Flanders Fields" in new interpretative contexts, which show how the past resonates with the present. Yet, synchronously, by staging encounters with various forms of heritage, the volume situates the 1914-1918 conflict as forever evasive, 
affectively remote and disturbing, as well as oversimplified by mediatic representations. Witnessing trauma via "In Flanders Fields" is thus conceptualized both as a paralysing burden and a source of inspiration and transformation. To remember and not to break faith, the central message of the poem, acquires surprising and thought-provoking meanings a hundred years after its publication. McCrae's elegy therefore becomes an important point of reference for a critical reassessment of the First World War, but also for a profound meditation on violence, loss, and the dynamics of remembrance.

\section{ACKNOWLEDGMENTS}

This work was supported by the Polish National Agency for Academic Exchange (NAWA), under grant number PPN/BEK/2018/1/00048/U/00001.

\section{REFERENCES}

Acton, Carol \& Jane Potter. 2015. Working in a world of hurt: Trauma and resilience in the narratives of medical personnel in warzones. Manchester University Press.

Ashplant, Timothy G., Graham Dawson \& Michael Roper. 2000. The politics of war memory and commemoration: Contexts, structures and dynamics. In Timothy G. Ashplant, Graham Dawson \& Michael Roper (eds.), The politics of war memory and commemoration, Routledge. 3-86. DOI: 10.4324/9781315080956-1

Atwood, Margaret. 2015. Poppies: Three variations. In Amanda Betts (ed.), In Flanders Fields: 100 years. Writing on war, loss and remembrance, Knopf Canada. 135-139.

Audoin-Rouzeau, Stéphane \& Annette Becker. 2014. 14-18: Understanding the Great War (translated by Catherine Temerson). Hill \& Wang.

Bourke, Joanna. 1996. Dismembering the male: Men's bodies, Britain, and the Great War. Reaktion Books.

Boyden, Joseph. 2015. Three tours of Flanders. In Amanda Betts (ed.), In Flanders Fields: 100 years. Writing on war, loss and remembrance, Knopf Canada. 217-224.

Carden-Coyne, Ana. 2014. The politics of wounds: Military patients and medical power in the First World War. Oxford University Press.

Clarke, George Elliott. 2015. From the diary of William Andrew White. In Amanda Betts (ed.), In Flanders Fields: 100 years. Writing on war, loss and remembrance, Knopf Canada. 227-235.

Cook, Tim. 2015. Forged in fire. In Amanda Betts (ed.), In Flanders Fields: 100 years. Writing on war, loss and remembrance, Knopf Canada. 17-55.

Dallaire, Roméo. 2015. Those who serve. In Amanda Betts (ed.), In Flanders Fields: 100 years. Writing on war, loss and remembrance, Knopf Canada. 1-14.

Dallaire, Roméo, with Jessica Dee Humphreys. 2016. Waiting for first light: My ongoing battle with PTSD. Penguin Random House. 
Davis, Wade. 2015. Of war and remembrance. In Amanda Betts (ed.), In Flanders Fields: 100 years. Writing on war, loss and remembrance, Knopf Canada. 141-169.

Dryden, Ken. 2015. The torch In Amanda Betts (ed.), In Flanders Fields: 100 years. Writing on war, loss and remembrance, Knopf Canada. 97-101.

Duffy, Carol Ann. 2009. Last post. https://www.thepoetryexchange.co.uk/last-post-carol-ann-duffy (accessed 20/08/2019).

Erll, Astrid. 2009. Wars we have seen: Literature as a medium of collective memory in the "age of extremes". In Elena Lamberti \& Vita Fortunati (eds), Memories and representations of war: The case of World War I and World War II, Brill/Rodopi. 25-43. DOI: 10.1163/9789042026292_003

Erll, Astrid \& Ann Rigney. 2009. Introduction: Cultural memory and its dynamics. In Astrid Erll $\&$ Ann Rigney (eds.), Mediation, remediation, and the dynamics of cultural memory, DeGruyter. 1-12.

Fussell, Paul. 1975. The Great War and modern memory. Oxford University Press.

Gegner, Martin \& Bart Ziino. 2011. Introduction. The heritage of war: Agency, contingency, identity. In Martin Gegner \& Bart Ziino (eds), The heritage of war, Routledge. 1-15.

Herman, Judit. 1992. Trauma and recovery. The aftermath of violence-from domestic abuse to political terror. Basic Books.

Hirsch, Marianne. 2016. Vulnerable times. In Judith Butler, Zeynep Gambetti \& Leticia Sabsay (eds), Vulnerability in resistance, Duke University Press. 76-96. DOI: 10.1215/9780822373490-005

Horne, John. 2014. The Great War at its centenary. In Jay Winter (ed.), The Cambridge history of the First World War. Vol. 3: Civil society, Cambridge University Press. 618-639. DOI: 10.1017/CHO9780511675683.031

Hurst, John E. 2003. John McCrae's wars. In Briton C. Busch (ed.), Canada and the Great War: Western Front Associations papers, McGill-Queen's University Press. 66-77.

Itani, Frances. 2015. Messages to the living, messages to the dead. In Amanda Betts (ed.), In Flanders Fields: 100 years. Writing on war, loss and remembrance, Knopf Canada. 171-185.

Janigan, Mary. 2015. Treason to their memory. In Amanda Betts (ed.), In Flanders Fields: 100 years. Writing on war, loss and remembrance, Knopf Canada. 75-95.

Ladino, Jennifer K. 2019. Memorials matter: Emotion, environment and public memory at American historical sites. University of Nevada Press.

Lane, Patrick. 2015. The wars. In Amanda Betts (ed.), In Flanders Fields: 100 years. Writing on war, loss and remembrance, Knopf Canada. 59-72.

Lifton, Robert J. 1996 [1979]. The broken connection: On death and the continuity of life. Washington and London: American Psychiatric Press, Inc.

Lloyd, David W. 1998. Battlefield tourism: Pilgrimage and the commemoration of the Great War in Britain, Australia and Canada, 1919-1939. Berg.

McGregor Hannah, Julie Rak \& Erin Wunker. 2018. Introduction: Living in the ruins. In Hannah McGregor, Julie Rak \& Erin Wunker (eds), Refuse: CanLit in Ruins, Book*hug. 9-28.

Moody, Jessica. 2015. Heritage and history. In Emma Waterton \& Steve Watson (eds.), The Palgrave handbook of contemporary heritage research, Palgrave Macmillan. 113-129.

Moscovitch, Hannah. 2013. Interview with the playwright by Anusree Roy. In Hannah Moscovitch, This is war, Playwrights Canada Press. 123-146.

Moscovitch, Hannah. 2015. Writing about war. In Amanda Betts (ed.), In Flanders Fields: 100 years. Writing on war, loss and remembrance, Knopf Canada. 237-244. 
Olick, Jeffrey K. 2008. From collective memory to the sociology of mnemonic practices and products. In Astrid Erll \& Ansgar Nünning (eds), Cultural memory studies: An international and interdisciplinary handbook, De Gruyter. 151-162. DOI: 10.1515/9783110207262.3.151

Owen, Wilfred. 1973 [1917]. Dulce et Decorum Est. In Frank Kermode \& John Hollander (eds), Modern British literature, Oxford University Press. 542.

Patterson, Kevin. 2015. Soldier surgeon, soldier poet. In Amanda Betts (ed.), In Flanders Fields: 100 years. Writing on war, loss and remembrance, Knopf Canada. 113-131.

Rigney, Ann. 2008. The dynamics of remembrance: Texts between monumentality and morphing. In Astrid Erll \& Ansgar Nünning (eds), Cultural memory studies: An international and interdisciplinary handbook, De Gruyter. 345-353.

Silverman, Helaine. 2015. Heritage and authenticity. In Emma Waterton \& Steve Watson (eds.), The Palgrave handbook of contemporary heritage research, Palgrave Macmillan. 6988.

Vance, Jonathan F. 1997. Death so noble: Memory, meaning and the First World War. University of British Columbia Press.

Vance, Jonathan F. 2005. Remembering Armageddon. In David Mackenzie (ed.), Canada and the First World War: Essays in honour of Robert Craig Brown, University of Toronto Press. 409-433.

Vance, Jonathan F. 2015. A moment's perfection. In Amanda Betts (ed.), In Flanders Fields: 100 years. Writing on war, loss and remembrance, Knopf Canada. 189-205.

Viejo-Rose, Dacia \& Marie Louise Stig Sørensen. 2015. Cultural heritage and armed conflict: New questions for an old relationship. In Emma Waterton \& Steve Watson (eds.), The Palgrave handbook of contemporary heritage research, Palgrave Macmillan. 281-296.

Waterton, Emma \& Steve Watson. 2015a. Heritage as a focus of research: Past, present and new directions. In Emma Waterton \& Steve Watson (eds.), The Palgrave handbook of contemporary heritage research, Palgrave Macmillan. 1-17.

Waterton, Emma \& Steve Watson. 2015b. The ontological politics of heritage; or how research can spoil a good story. In Emma Waterton \& Steve Watson (eds.), The Palgrave handbook of contemporary heritage research, Palgrave Macmillan. 21-36.

Winter, Caroline. 2016. Celebrating peace and commemorating war in the city of Ieper. In Keir Reeves, Geoffrey R. Bird, Laura James, Birger Stichelbaut \& Jean Bourgeois (eds), Battlefield events: Landscape, commemoration and heritage, Routledge. 77-96.

Winter, Jay. 1999. Forms of kinship and remembrance in the aftermath of the Great War. In Jay Winter \& Emmanuel Sivan (eds), War and remembrance in the twentieth century, Cambridge University Press. 40-60. DOI: 10.1017/CBO9780511599644.004

Winter, Jay. 2001. The memory boom in contemporary historical studies. Raritan 21(1). 52-66.

Winter, Jay. 2014. Families. In Jay Winter (ed.), The Cambridge history of the First World War. Vol. 3: Civil society, Cambridge University Press. 46-68. DOI: 10.1017/CHO9780511675683.005 